\title{
Corrosion Behavior of Passivated 316LSS with Ag Coating as PEMFC Bipolar Plate
}

\author{
Naibao Huang, ${ }^{1}$ Chenghao Liang, ${ }^{1}$ Hongtao Wang, ${ }^{2}$ Lishuang $\mathrm{Xu},{ }^{3}$ and Hongfeng $\mathrm{Xu}^{3}$ \\ ${ }^{1}$ Transportation Equipments and Ocean Engineering College, Dalian Maritime University, Dalian 116026, China \\ ${ }^{2}$ Department of Marine Engineering, Jiangsu Maritime Institute, Nanjing 211170, China \\ ${ }^{3}$ Sunrise Power Co. Ltd., Dalian 116085, China \\ Correspondence should be addressed to Naibao Huang, hnaibao@163.com \\ Received 3 April 2011; Accepted 9 August 2011 \\ Academic Editor: F. J. M. Pérez
}

Copyright (C) 2011 Naibao Huang et al. This is an open access article distributed under the Creative Commons Attribution License, which permits unrestricted use, distribution, and reproduction in any medium, provided the original work is properly cited.

\begin{abstract}
A new chemical passivation technique, which contained $20 \mathrm{~g} / \mathrm{L}$ hydrogen peroxide, $3.75 \mathrm{~g} / \mathrm{L}$ sodium silicate, $1.25 \mathrm{~g} / \mathrm{L}$ sodium carbonate, $3.75 \mathrm{~g} / \mathrm{L}$ lactic acid and $0.75 \mathrm{~g} / \mathrm{L} 8$-hydroxyquinoline, was used to modify 316 stainless steel with Ag coating (Ag-coated 316SS) as PEMFC bipolar plates. The results indicated that the compact passive film had been obtained on the surface of Agcoated 316SS. The passivation process could not only increase contact angle (from $58^{\circ}$ to $104^{\circ}$ ) but also decreased pinhole defects of Ag-coated 316SS. Electrochemical test manifested that the passivation process could reduce Ag-coated 316SS's double layer capacitance $\left(C_{d}\right)$, and increase its charge transfer resistance. So, it provided significant protection against corrosion for Ag-coated $316 \mathrm{SS}$ in PEMFC environment.
\end{abstract}

\section{Introduction}

Owing to its virtue of high efficiency, high-power density, low-temperature operation, fast and easy startup, and so forth, proton exchange membrane fuel cell (PEMFC) is gaining worldwide interest $[1,2]$. However, expensive cost restricts its using in large-scale market [3]. Bipolar plate is one of the most expensive components in PEMFC system. The widely used bipolar plate materials are graphite or graphite compounds [4-6]. High cost and brittleness of graphite bipolar plate limit them to large-scale applications. Therefore, many researchers aim to investigate substitute materials including carbon composite materials, light metal materials [7-10], Fe-based alloys, stainless steels [11, 12], and Ni-based materials [13-15]. Among these alternative materials, stainless steel is a promising candidate due to its high mechanical strength, low cost, and easiness in mass production.

Davies et al. [16] proved that fuel cell performance improved with chromium and nickel contents of stainless steel bipolar plates increasing. Brady et al. [17] proposed using $\mathrm{Cr}$ nitride layer to decrease the corrosion of stainless steel bipolar plate and obtained promising results $[18,19]$.
Based on these results, many researchers had investigated the characteristic of stainless steel bipolar plates with chromium or chromium compound coatings [13, 20-27]. Although it seemed that stainless steel with chromium-based film or carbide coatings $[28,29]$ had become promising materials for PEMFC bipolar plate, a few of companies use them as bipolar plates in fuel cell stack until now. On the contrary, stainless steel bipolar plates with noble metal coatings were still the most suitable materials by considering corrosion resistance and conductivity. For example, Wind et al. [30] had shown that the performance of 316L bipolar plate with gold coating was similar to that of graphite. Wang et al. also confirmed that fuel cell performance of gold-plated titanium bipolar plate was better than that of graphite and pure titanium bipolar plates [9]. The characteristics of titanium bipolar plates with iridium oxide and platinum coatings were close to that of graphite bipolar plate [31]. Yoon et al. [32] evaluated the characteristics of 304SS, 310SS, and 316SS with different coatings, which included gold $(2 \mathrm{~nm}, 10 \mathrm{~nm}$, and $1 \mu \mathrm{m})$, titanium, zirconium, zirconium nitride $(\mathrm{ZrN})$, zirconium niobium $(\mathrm{ZrNb})$, and zirconium nitride on gold coating $(\mathrm{ZrNAu})$. The results showed that the samples with a relatively thick gold coating $(>10 \mathrm{~nm})$ on $\mathrm{Zr}$ coating satisfied 
the USA Department of Energy (USA DOE) target for contact resistance and corrosion resistance. However, the high cost of noble metal coatings confines its application. Since silver is a kind of relative low-cost noble metal material, electrodepositing Ag, a conventional technology for surface treatment, is suitable for protecting PEMFC stainless steel bipolar plate. Ag coatings on metallic bipolar plates have not been sufficiently viable due to pinhole defects, which are prone to corrosion and thus destroy the whole protecting film. To make defect-free coatings, methods to mitigate the presence of pinhole defects must be pursued.

In our research, a new chemical passivation technique was developed to reduce the defects of Ag-coated 316SS bipolar plate (original BP) and improve its corrosion resistance. At the same time, the bipolar plate's electrochemical characteristic, contact angle, interfacial conductivity, and surface topography were also investigated.

\section{Experimental}

2.1. Chemical Passivation of $316 S S$ with Ag Coating. Agcoated 316SS bipolar plates (original BP, $200 \times 350 \times$ $1 \mathrm{~mm}$ ) were supplied by Sunrise Power Co., Ltd. (Dalian, China). The samples were cut into $30 \times 40 \times 1 \mathrm{~mm}$ slices. Before use, the samples were degreased with acetone in ultrasonic bath for $12 \mathrm{~min}$, dried with nitrogen, and then etched with $10 \%$ sulphuric acid solution for $5 \mathrm{~min}$, rinsed in deionized water. At last, the treated samples were put into nonchromium passivation solution for $5 \mathrm{~min}$, which was composed of $20 \mathrm{~g} / \mathrm{L}$ hydrogen peroxide, $3.75 \mathrm{~g} / \mathrm{L}$ sodium silicate, $1.25 \mathrm{~g} / \mathrm{L}$ sodium carbonate, $3.75 \mathrm{~g} / \mathrm{L}$ lactic acid, and $0.75 \mathrm{~g} / \mathrm{L} \quad 8$-hydroxyquinoline. The optimized temperature was $30^{\circ} \mathrm{C}$. Then, the sample was rinsed in deionized water, immersed in hot water at $50^{\circ} \mathrm{C}$ for $1 \mathrm{~min}$, and dried with warm air. The passivated bipolar plates (passive BP) were obtained and stored in a desiccator.

2.2. Surface Morphology. The micrography of original BP and passive BP were observed using Nano-scope IIIa Atomic Force Microscopy (AFM, Digital Instruments). Contact angles were measured using the sessile drop method with a Dataphysics OCA 20 contact angle analyzer. The drop size of ultrapure water was $1 \mu \mathrm{L}$ to avoid the weight effect. The digital drop image was processed by an image analysis system, which calculated both the left and right contact angles from the shape of the drop with an accuracy of $\pm 0.1^{\circ}$.

2.3. Electrochemical Tests. Electrochemical measurements were carried out on Princeton Applied Research equipment (VMP3). The procedure was controlled by EC-Lab software. Princeton flat cell was used for the electrochemical experiments. The working electrode was original $\mathrm{BP}$ and passive BP with exposure area $1 \mathrm{~cm}^{2}$. A platinum grid was used as counterelectrode, and the reference electrode was saturated calomel electrode (SCE, saturated $\mathrm{KCl}$ ). Solution used for electrochemical tests was $0.5 \mathrm{~mol} \cdot \mathrm{L}^{-1} \mathrm{H}_{2} \mathrm{SO}_{4}+2 \mathrm{ppm} \mathrm{\textrm {F } ^ { - }}$. In order to simulate anodic and cathodic environment of PEMFC, the test coupon was put into the solution after it was bubbled with pure hydrogen gas $\left(\mathrm{H}_{2}\right)$ for $2 \mathrm{~h}$ and with air for $1 \mathrm{~h}$, respectively. Electrochemical impedance spectroscopy (EIS) was made at the open circuit potential with a $5 \mathrm{mV}$ ac perturbation that was controlled between $100 \mathrm{kHz}$ and $0.01 \mathrm{~Hz}$. The sample was stabilized at OCP for $1 \mathrm{~h}$ and then was polarized from OCP to positive direction with a scan rate of $1 \mathrm{mVs}^{-1}$. In order to investigate the stability of passive BP under PEMFC operation conditions, potentiostatic test was conducted at simulated anodic and cathodic condition, respectively. The operating condition was as follow. In simulated cathodic condition, the sample was polarized at $0.6 \mathrm{~V}$ in the solution purged with air. While, in anodic environment, it was polarized at $-0.1 \mathrm{~V}$ in the solution purged with $\mathrm{H}_{2}$. All tests were conducted at $80^{\circ} \mathrm{C}$.

\section{Results and Discussion}

3.1. Surface Morphology. Figure 1 represented AFM of original BP and passive BP. From Figure 1, the vertical height of the sample's surface was decreased from $200 \mathrm{~nm}$ to below $100 \mathrm{~nm}$ after it was passivated. Comparing with original BP, the surface of passive BP was smoother although there was crimp on its surface, which maybe comes from 316SS matrix. Meanwhile, the clearance between Ag granule and Ag granule was diminished dramatically on the surface of passive BP. That is, the nonchromium passivation reduced the original BP's pinhole defects.

3.2. Contact Angle and Contact Resistance. Contact angles of original $\mathrm{BP}$ and passive $\mathrm{BP}$ were shown in Figure 2. Contact angles for the former and the latter were $58^{\circ}$ and $104^{\circ}$, respectively. The latter was indicative of more hydrophobic than the former. In PEMFC system, in order to prevent proton exchange membrane from dehydration, the inlet gases need to be humidified. At the same time, electrochemical reaction could produce water. So there exited many water in PEMFC system. For maintaining highpower output, the liquid water including humidified and produced water, which would flood membrane electrode assembly (MEA), must be removed in time. Since water was difficult to adhere to hydrophobic bipolar plate, using hydrophobic bipolar plate was beneficial not only for water management but also for decreasing corrosion from the weak acid solution. From Figure 2, original BP changed from hydrophilicity to hydrophobicity after passivation. That is, bipolar plate's surface energy was decreased. Obviously, a partially hydrophobic surface of the plate material might be more beneficial for removing water from gas diffusion layer (GDL) and decreasing corrosion from the weak acid solution.

PEMFC's output power had something to do with its internal resistance. Contact resistance between bipolar plate and MEA played an important role in the internal resistance. Figure 3 illustrated contact resistance of original BP and passive BP with Toray carbon paper. Nowadays, the range of 0.8-1.2 MPa compact pressure was often applied to PEMFC stack. So the data of contact resistance between $0.8-1.2 \mathrm{MPa}$ were recorded. From Figure 3, the contact resistance for 


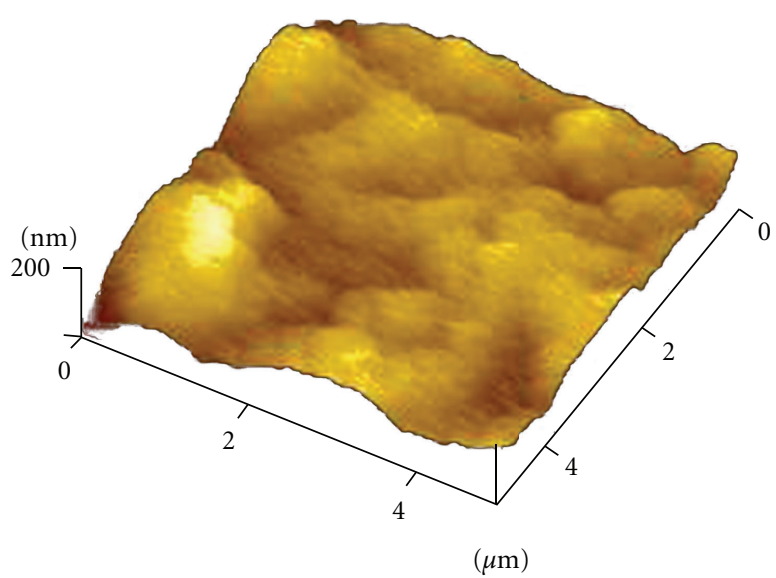

(a) The original bipolar plate

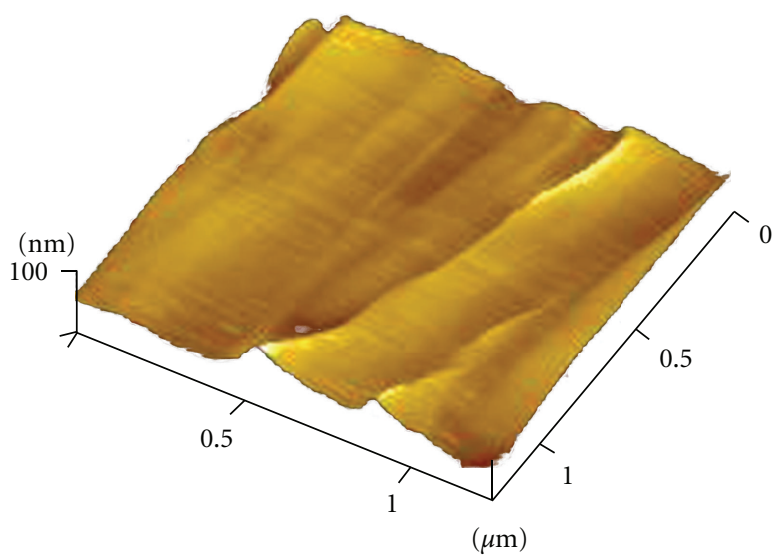

(b) The passive bipolar plate

Figure 1: Atomic force microscopy of the original and the passive bipolar plates.

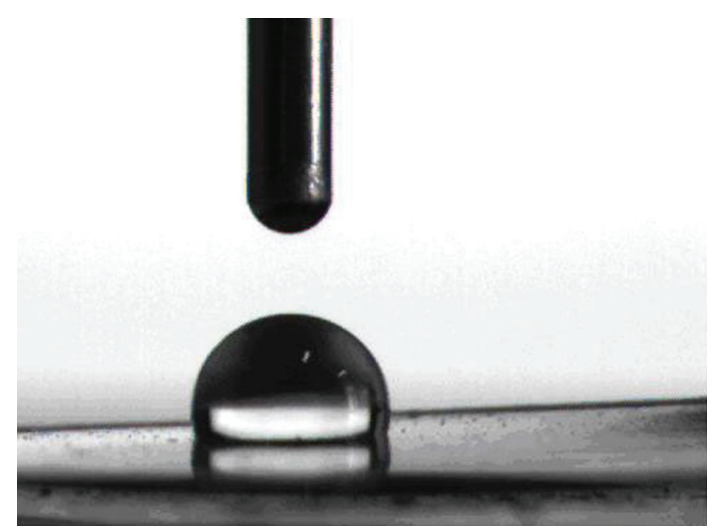

(a) The passive bipolar plate

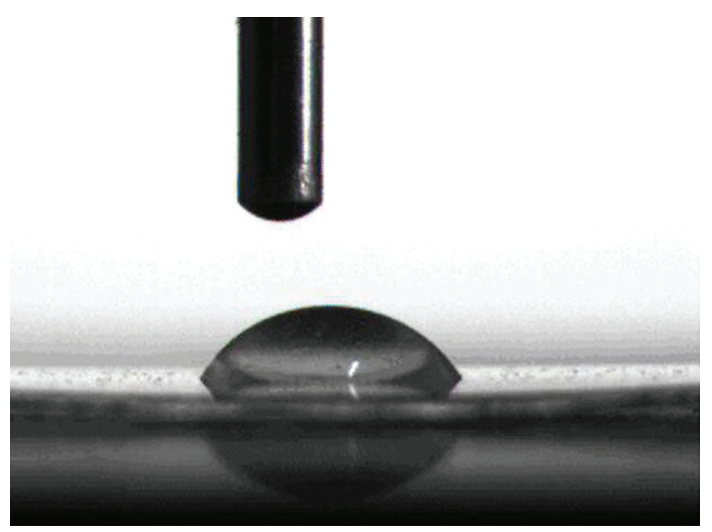

(b) The original bipolar plate

FIGURE 2: Contact angle of the original and the passive bipolar plates with water.

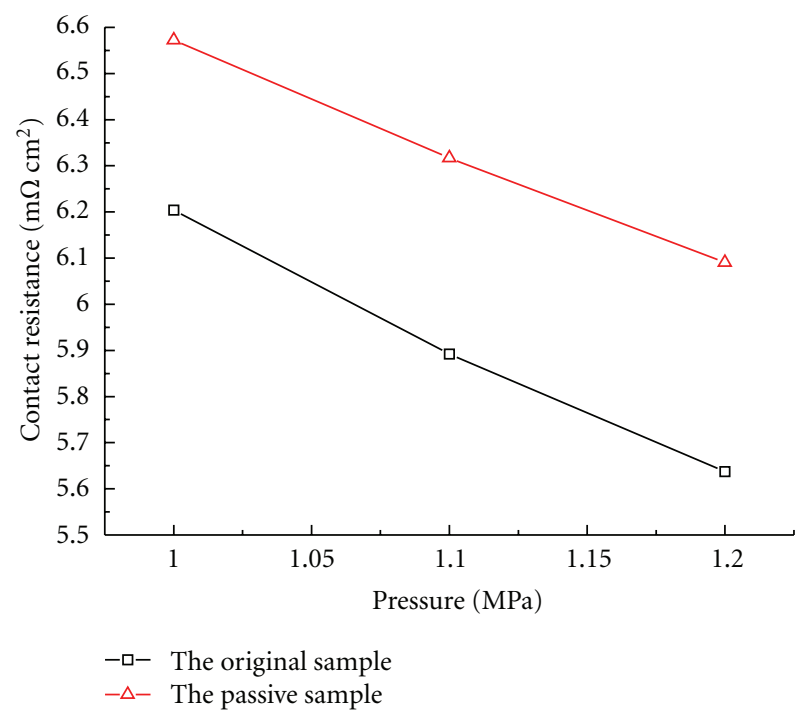

FIGURE 3: Contact resistance of the original and the passive bipolar plates. 


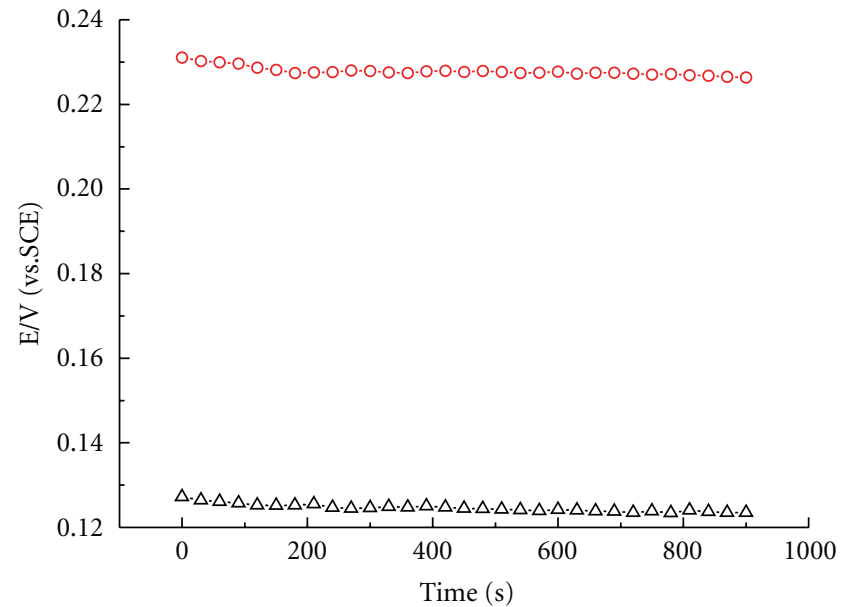

$-\Delta-$ The original sample -o- The passive sample

(a) Simulated cathodic environment

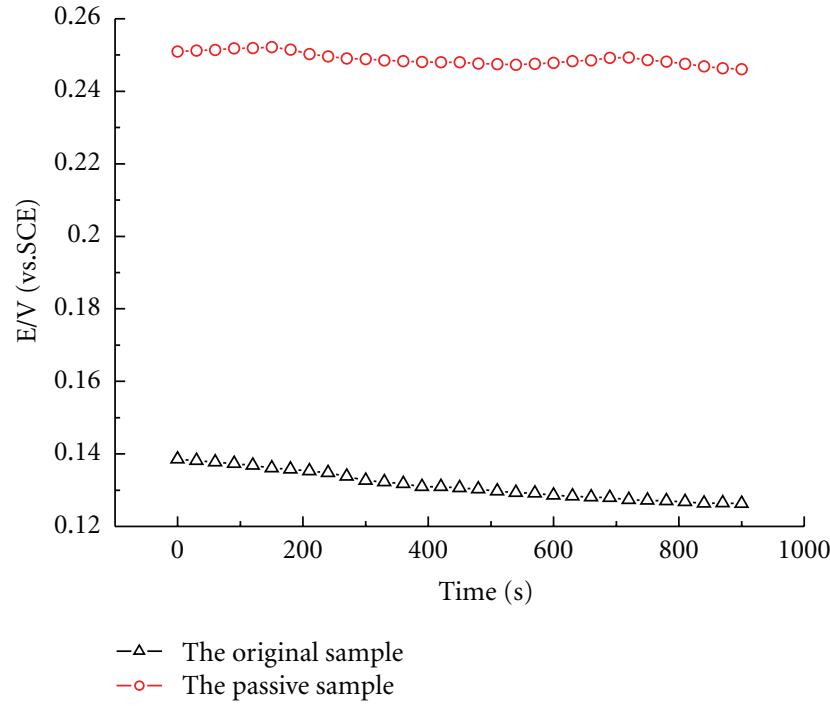

(b) Simulated anodic environment

Figure 4: Plot of $\mathrm{E}_{\mathrm{OCP}}$ versus time for the original and the passive bipolar plates in simulated PEMFC environment.

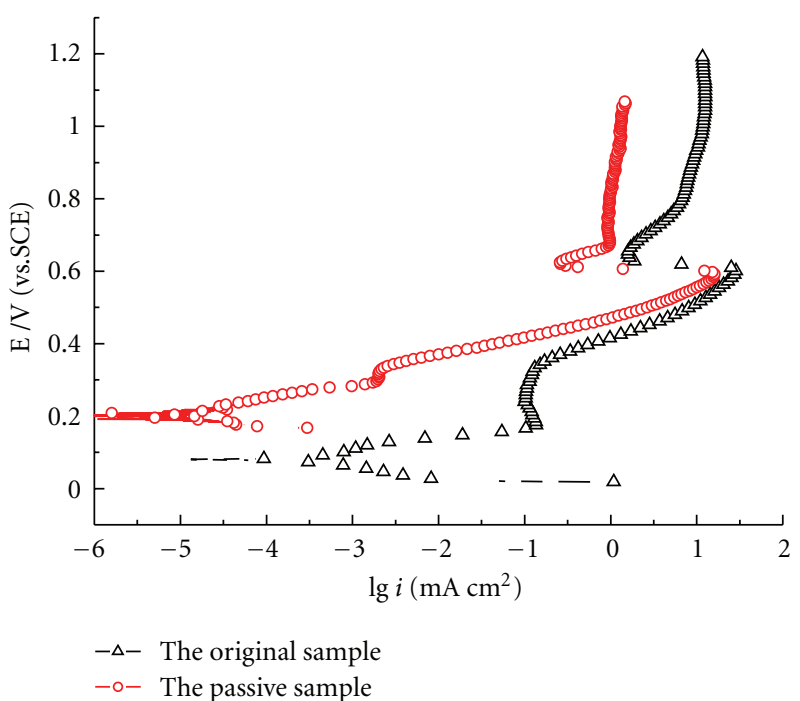

(a) Simulated cathodic environment

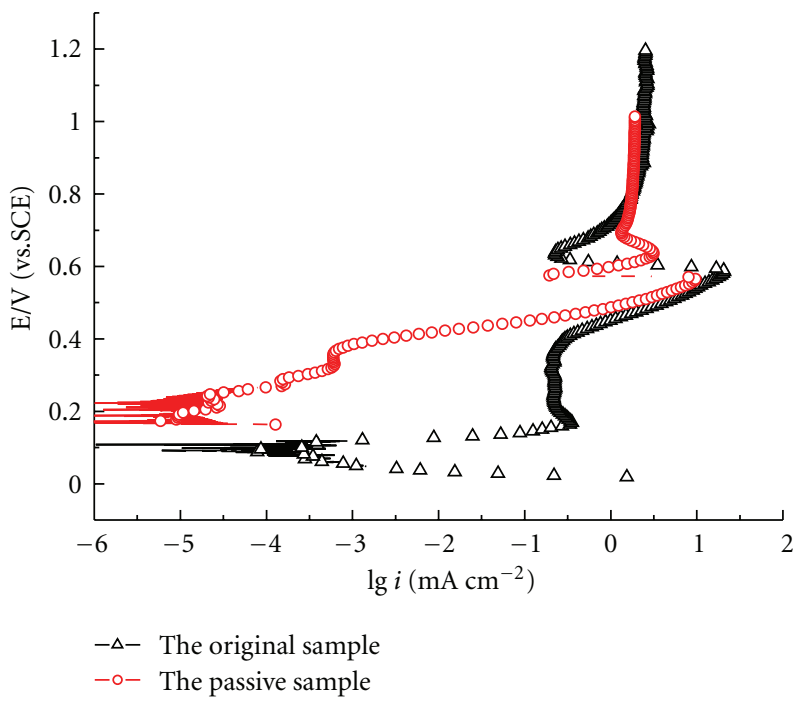

(b) Simulated anodic environment

FIGURE 5: Polarization curves of the original and the passive bipolar plates in simulated PEMFC environment.

original $\mathrm{BP}$ was in the range of $6.20 \times 10^{-3}-5.64 \times$ $10^{-3} \Omega \mathrm{cm}^{-2}$. When original BP was passivated, its contact resistance was $6.57 \times 10^{-3}-6.09 \times 10^{-3} \Omega \mathrm{cm}^{-2}$. The contact resistance of passive $\mathrm{BP}$ was a little bigger than that of original $\mathrm{BP}$ when the compact pressure was over 1.0 $\mathrm{MPa}$. Since the increased contact resistance was about $4.00 \times 10^{-4} \Omega \mathrm{cm}^{-2}$, the passivation process for original BP may not lead to decreasing PEMFC's output power.

\subsection{Electrochemical Characteristic}

3.3.1. Open Circuit Potential (OCP). Figure 4 illustrates the curves of OCP versus time for samples in simulated PEMFC environment. After original BP was passivated, its OCP value increased from $0.12 \mathrm{~V}$ to $0.23 \mathrm{~V}$ in simulated cathodic environment, and the stabilized value, about $0.23 \mathrm{~V}$, was obtained as soon as it was immersed in the test solution for $30 \mathrm{~min}$, while that value increased from $0.13 \mathrm{~V}$ to $0.25 \mathrm{~V}$ in anodic environment. Since the homogeneous and compact passivation layer was formed on the surface of original BP, its OCP moved toward positive whether it was immersed in simulated cathodic or anodic environment.

3.3.2. Potentiodynamic Polarization Curves and EIS. Potentiodynamic polarization curves of original $\mathrm{BP}$ and passive $\mathrm{BP}$ were given in Figure 5. Whether in anodic environment or cathodic environment, the current density of passive BP was smaller than that of original BP. For example, when the 


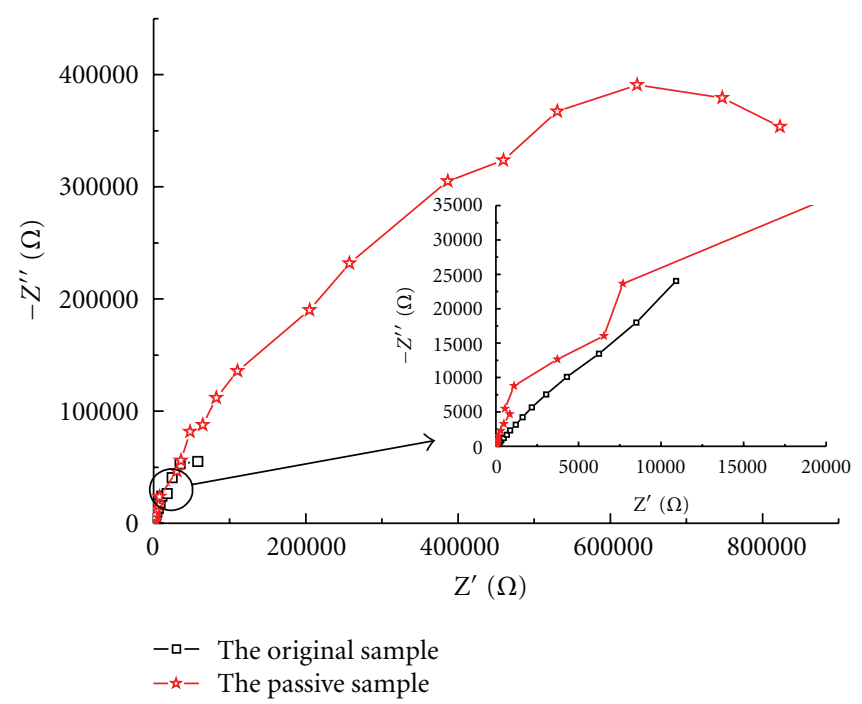

(a) Simulated cathodic environment

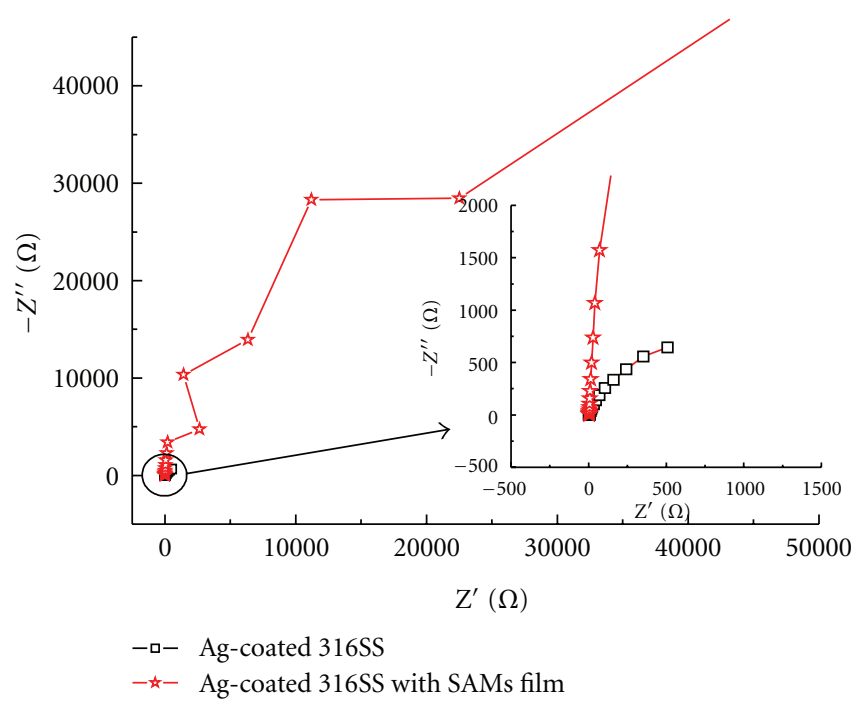

(b) Simulated anodic environment

FIGURE 6: Nyquist curves of the original and the passive bipolar plates in simulated PEMFC environment.

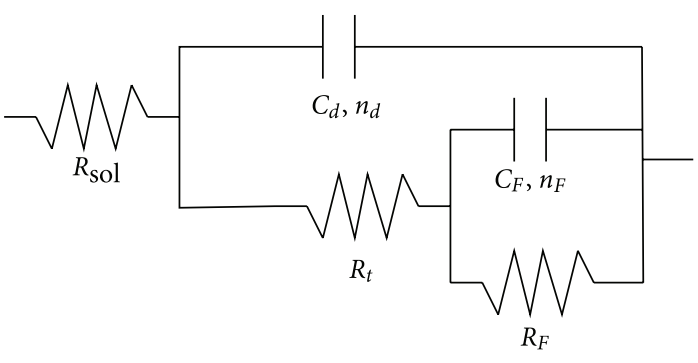

(a) The original bipolar plate

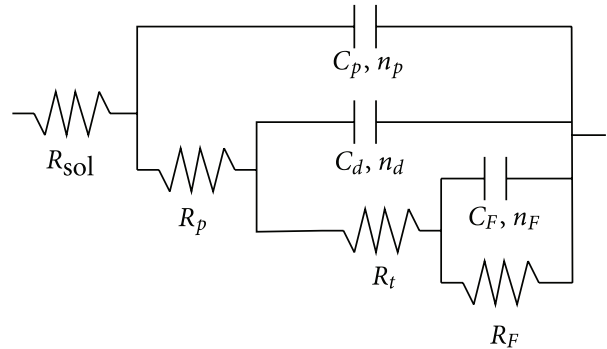

(b) The passive bipolar plate

FIGURE 7: Equivalent circuit of the original and the passive bipolar plates in simulated PEMFC environment.

polarization potential was $0.4 \mathrm{~V}$, in cathodic environment, the polarization current densities for original $\mathrm{BP}$ and passive BP were $0.593 \mathrm{~mA} \mathrm{~cm}^{-2}$ and $4.44 \times 10^{-2} \mathrm{~mA} \mathrm{~cm}^{-2}$, respectively. The original BP's current density decreased about two orders of magnitude by passivation process, whereas, the corresponding values were $0.296 \mathrm{~mA} \mathrm{~cm}^{-2}$ and 2.27 $\times 10^{-3} \mathrm{~mA} \mathrm{~cm}^{-2}$ in anodic environment, respectively. The current density decreased about two orders of magnitude.

Figure 6 presented Nyquist plots of impedance spectra for original BP and passive BP in simulated PEMFC environment. From Figure 6, the capacitance of passive BP was greater than that of original $\mathrm{BP}$ whether it was in anodic environment or in cathodic environment. The equivalent circuit models based on Takenouti's model [33] were shown in Figure 7. Figure 7(a) is for original BP, and Figure 7(b) is for passive BP. The elements presented in the figure were shown as follows. $R_{\text {sol }}$ was the solution resistance between the reference electrode and the counter electrode; $C_{P}$ and $R_{P}$ denoted the capacitance and electrical leakage through the passive film; $C_{F}$ and $R_{F}$ represented the capacitance and electrical leakage through ionic conduction of the $\mathrm{Ag}$ film, respectively. $C_{d}$ and $R_{t}$ corresponded to the doublelayer capacitance and charge transfer resistance. Comparing to original $\mathrm{BP}, C_{P}$ and $R_{P}$, which attributed to the passive film, appeared in the equivalent circuit (Figure $7(b)$ ). Since the same corrosion solution and original BP were used, $R_{\text {sol }}, C_{F}$, and $R_{F}$ for original $\mathrm{BP}$ and passive $\mathrm{BP}$ seemed to resemble each other closely. So the passivation for original BP led to remarkable effect, the characteristic of electrical double layer. The EIS data were fitted using ZsimpWin software (EG\&G) are summarized in Table 1. After the original BP was passivated, its double-layer capacitance $\left(C_{d}\right)$ decreased from $6.82 \times 10^{-4} \mathrm{~F} \mathrm{~cm}^{-2}$ to $2.74 \times 10^{-7} \mathrm{~F} \mathrm{~cm}^{-2}$ in cathodic environment, while its charge transfer resistance $\left(R_{t}\right)$ increases from $2.75 \times 10^{3} \Omega \mathrm{cm}^{2}$ to $1.64 \times 10^{6} \Omega \mathrm{cm}^{2}$. In anodic environment, the corresponding $C_{d}$ value decreases from $5.32 \times 10^{-5} \mathrm{~F} \mathrm{~cm}^{-2}$ to $2.72 \times 10^{-7} \mathrm{~F} \mathrm{~cm}^{-2}$, and its $R_{t}$ increases from $1.17 \times 10^{3} \Omega \mathrm{cm}^{2}$ to $4.46 \times 10^{4} \Omega \mathrm{cm}^{2}$. The decrease and the increase of $C_{d}$ and $R_{t}$ implied that the compact passive film was formed on the surface, which meant that the passivation process provided significant protection against corrosion.

3.3.3. Potentiostatic Polarization Curves. In PEMFC's operation environment, the major concern for bipolar plate materials is its anticorrosion characteristic and stability. 


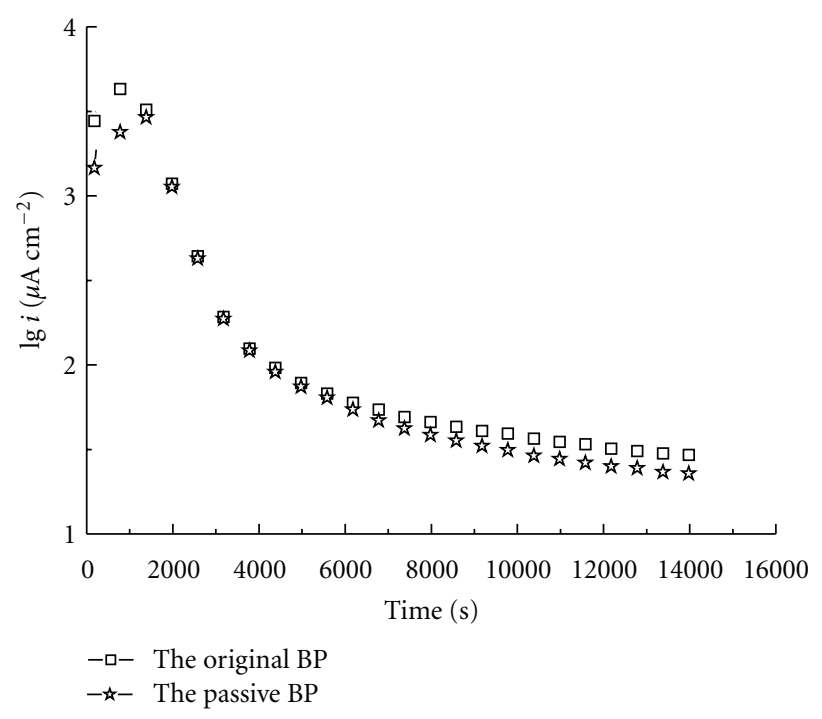

(a) Simulated cathodic environment

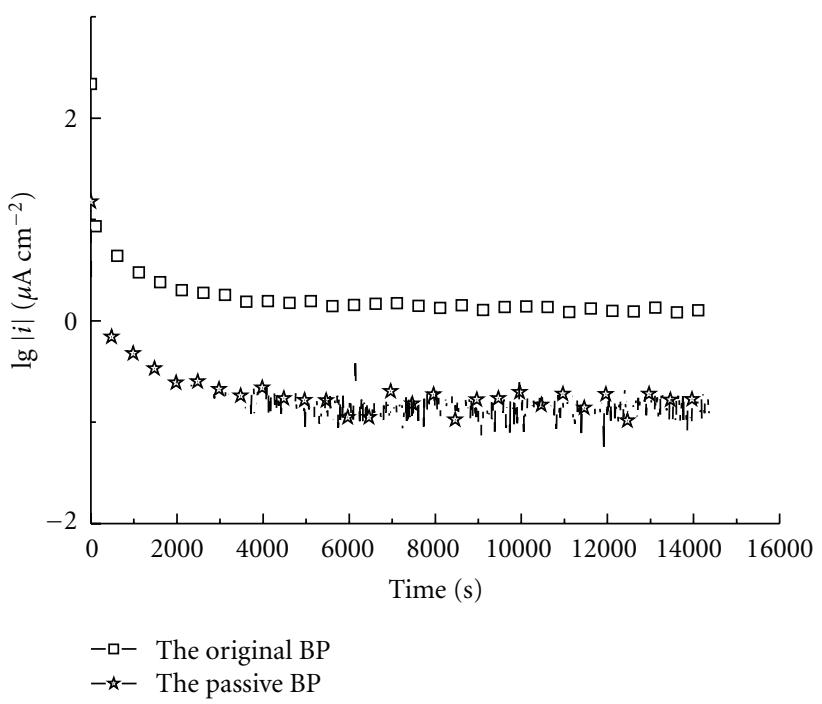

(b) Simulated anodic environment

FIgURE 8: Potentiostatic polarization curve of the original and the passive bipolar plates in simulated PEMFC operation condition.

TABLE 1: Values of the elements in equivalent circuits. (a) Simulated cathodic environment; (b) simulated anodic environment.

(a) Simulated cathodic environment

\begin{tabular}{lccc} 
& $R_{\text {sol }} / \Omega \mathrm{cm}^{2}$ & $C_{d} / \mathrm{F} \mathrm{cm}^{-2}$ & $R_{t} / \Omega \mathrm{cm}^{2}$ \\
\hline The original BP & 3.78 & $6.82 \times 10^{-4}$ & $2.75 \times 10^{3}$ \\
The passive BP & 4.39 & $2.73 \times 10^{-7}$ & $1.64 \times 10^{6}$ \\
\hline
\end{tabular}

(b) Simulated anodic environment

\begin{tabular}{lccc} 
& $R_{\text {sol }} / \Omega \mathrm{cm}^{2}$ & $C_{d} / \mathrm{F} \mathrm{cm}^{-2}$ & $R_{t} / \Omega \mathrm{cm}^{2}$ \\
\hline The original BP & 2.37 & $5.32 \times 10^{-5}$ & $1.17 \times 10^{3}$ \\
The passive BP & 3.80 & $2.72 \times 10^{-7}$ & $4.46 \times 10^{5}$ \\
\hline
\end{tabular}

Potentiostatic tests were conducted to study the corrosion behavior of the bipolar plate in simulated actual PEMFC working condition. The results were illustrated in Figure 8. In cathodic condition, the current densities of original $\mathrm{BP}$ and passive BP decreased gradually with immersion time lengthening. There was no difference in 6000 seconds. After 6000 seconds, the current density for passive BP decreased continuously and the stabilized value, about 2.30 $\times 10^{-2} \mathrm{~mA} \mathrm{~cm}^{-2}$, was obtained, while that for original BP was about $3.00 \times 10^{-2} \mathrm{~mA} \mathrm{~cm}^{-2}$. In anodic condition, the current densities for the two bipolar plates decreased quickly within 2000 seconds. Then, they reached the steady values, which were $1.92 \times 10^{-3} \mathrm{~A} \mathrm{~cm}^{-2}$ for original $\mathrm{BP}$ and $6.70 \times 10^{-4} \mathrm{~A} \mathrm{~cm}^{-2}$ for passive $\mathrm{BP}$, respectively. All the results indicated that the passivation process could decrease the corrosion rate of bipolar plate in simulate PEMFC operation condition. Since vast amounts of hydrogen ions were contained in simulated anodic operation condition, and its radius is small, it could easily pass across the defects and the pinhole in the Ag film. When the bipolar plate was passivated, the defects and the pinhole were decreased and Ag film became compact. As a whole, we could conclude that the passivation process could improve the corrosion resistance of original BP. Its long-term effect needs to be conducted in the coming work.

\section{Conclusions}

A new chemical passivation technique was used to modify Ag-coated 316SS as PEMFC bipolar plates. The results indicated that the compact passive film had been obtained on the surface of Ag-coated 316SS. The passivation process could not only increase original BP's contact angle, which was helpful to water management, but also decrease surface roughness and reduce the pinhole defects of Ag coating. Electrochemical test confirmed that the passivation process reduced bipolar plate's double-layer capacitance $\left(C_{d}\right)$ and increased its charge transfer resistance. So it provided significant protection against corrosion for 316SS with Ag coating in PEMFC environment.

\section{Acknowledgments}

This work is financially supported by the National HighTechnology Research and Development Program of China (863 Program, no. 2009AA05Z120). The work is also supported by the Young Teachers Program of Dalian Maritime University (DLMU-ZL-200720).

\section{References}

[1] N. Rajalakshmi, S. Pandian, and K. S. Dhathathreyan, "Vibration tests on a PEM fuel cell stack usable in transportation application," International Journal of Hydrogen Energy, vol. 34, no. 9, pp. 3833-3837, 2009.

[2] S. Barrett, "The European hydrogen and fuel cell strategic research agenda and deployment strategy," Fuel Cells Bulletin, vol. 2005, no. 5, pp. 12-19, 2005. 
[3] K. Jayakumar, S. Pandiyan, N. Rajalakshmi, and K. S. Dhathathreyan, "Cost-benefit analysis of commercial bipolar plates for PEMFC's," Journal of Power Sources, vol. 161, no. 1, pp. 454-459, 2006.

[4] S. R. Dhakate, R. B. Mathur, B. K. Kakati, and T. L. Dhami, "Properties of graphite-composite bipolar plate prepared by compression molding technique for PEM fuel cell," International Journal of Hydrogen Energy, vol. 32, no. 17, pp. 45374543, 2007.

[5] I. U. Hwang, H. N. Yu, S. S. Kim et al., "Bipolar plate made of carbon fiber epoxy composite for polymer electrolyte membrane fuel cells," Journal of Power Sources, vol. 184, no. 1, pp. 90-94, 2008.

[6] R. Hornung and G. Kappelt, "Bipolar plate materials development using Fe-based alloys fo solid polymer fuel cells," Journal of Power Sources, vol. 72, no. 1, pp. 20-21, 1998.

[7] C. Shen, M. Pan, Z. Hua, and R. Yuan, "Aluminate cement/graphite conductive composite bipolar plate for proton exchange membrane fuel cells," Journal of Power Sources, vol. 166, no. 2, pp. 419-423, 2007.

[8] S. T. Myung, S. Sakurada, M. Kumagai, and H. Yashiro, "A promising alternative to PEMFC graphite bipolar plates: surface modified type 304 stainless steel with TiN nanoparticles and elastic styrene butadiene rubber particles," Fuel Cells, vol. 10, no. 4, pp. 545-555, 2010.

[9] S. H. Wang, J. Peng, W. B. Lui, and J. S. Zhang, "Performance of the gold-plated titanium bipolar plates for the light weight PEM fuel cells," Journal of Power Sources, vol. 162, no. 1, pp. 486-491, 2006.

[10] S. H. Wang, J. Peng, and W. B. Lui, "Surface modification and development of titanium bipolar plates for PEM fuel cells," Journal of Power Sources, vol. 160, no. 1, pp. 485-489, 2006.

[11] H. Wang and J. A. Turner, "Ferritic stainless steels as bipolar plate material for polymer electrolyte membrane fuel cells," Journal of Power Sources, vol. 128, no. 2, pp. 193-200, 2004.

[12] E. Fleury, J. Jayaraj, Y. C. Kim, H. K. Seok, K. Y. Kim, and K. B. Kim, "Fe-based amorphous alloys as bipolar plates for PEM fuel cell," Journal of Power Sources, vol. 159, no. 1, pp. 34-37, 2006.

[13] M. P. Brady, H. Wang, B. Yang et al., "Growth of Cr-Nitrides on commercial Ni-Cr and $\mathrm{Fe}-\mathrm{Cr}$ base alloys to protect PEMFC bipolar plates," International Journal of Hydrogen Energy, vol. 32, no. 16, pp. 3778-3788, 2007.

[14] Y. Wang and D. O. Northwood, "An investigation into TiNcoated 316L stainless steel as a bipolar plate material for PEM fuel cells," Journal of Power Sources, vol. 165, no. 1, pp. 293298, 2007.

[15] M. P. Brady, K. Weisbrod, I. Paulauskas et al., "Preferential thermal nitridation to form pin-hole free Cr-nitrides to protect proton exchange membrane fuel cell metallic bipolar plates," Scripta Materialia, vol. 50, no. 7, pp. 1017-1022, 2004.

[16] D. P. Davies, P. L. Adcock, M. Turpin, and S. J. Rowen, "Stainless steel as a bipolar plate material for solid polymer fuel cells," Journal of Power Sources, vol. 86, no. 1, pp. 237-242, 2000.

[17] M. P. Brady, K. Weisbrod, C. Zawodzinski, I. Paulauskas, R. A. Buchanan, and L. R. Walker, "Assessment of thermal nitridation to protect metal bipolar plates in polymer electrolyte membrane fuel cells," Electrochemical and Solid-State Letters, vol. 5, no. 11, pp. A245-A247, 2002.

[18] H. Wang, M. P. Brady, G. Teeter, and J. A. Turner, “Thermally nitrided stainless steels for polymer electrolyte membrane fuel cell bipolar plates part 1: model Ni-50Cr and austenitic 349 alloys," Journal of Power Sources, vol. 138, no. 1-2, pp. 86-93, 2004.

[19] H. Wang, M. P. Brady, K. L. More, H. M. Meyer, and J. A. Turner, "Thermally nitrided stainless steels for polymer electrolyte membrane fuel cell bipolar plates Part 2: beneficial modification of passive layer on AISI446," Journal of Power Sources, vol. 138, no. 1-2, pp. 79-85, 2004.

[20] I. E. Paulauskas, M. P. Brady, H. M. Meyer, R. A. Buchanan, and L. R. Walker, "Corrosion behavior of $\mathrm{CrN}, \mathrm{Cr} 2 \mathrm{~N}$ and $\pi$ phase surfaces on nitrided Ni-50Cr for proton exchange membrane fuel cell bipolar plates," Corrosion Science, vol. 48, no. 10, pp. 3157-3171, 2006.

[21] Y. Fu, M. Hou, G. Lin, J. Hou, Z. Shao, and B. Yi, "Coated 316L stainless steel with CrxN film as bipolar plate for PEMFC prepared by pulsed bias arc ion plating," Journal of Power Sources, vol. 176, no. 1, pp. 282-286, 2008.

[22] K. H. Cho, W. G. Lee, S. B. Lee, and H. Jang, "Corrosion resistance of chromized 316L stainless steel for PEMFC bipolar plates," Journal of Power Sources, vol. 178, no. 2, pp. 671-676, 2008.

[23] C. Y. Bai, M. D. Ger, and M. S. Wu, "Corrosion behaviors and contact resistances of the low-carbon steel bipolar plate with a chromized coating containing carbides and nitrides," International Journal of Hydrogen Energy, vol. 34, no. 16, pp. 6778-6789, 2009.

[24] N. D. Nam, J. H. Han, J. G. Kim, P. H. Tai, and D. H. Yoon, "Electrochemical properties of TiNCrN-coated bipolar plates in polymer electrolyte membrane fuel cell environment," Thin Solid Films, vol. 518, no. 22, pp. 6598-6603, 2010.

[25] R. Tian, "Chromium nitride/Cr coated 316L stainless steel as bipolar plate for proton exchange membrane fuel cell," Journal of Power Sources, vol. 196, no. 3, pp. 1258-1263, 2011.

[26] B. Wu, Y. Fu, J. Xu, G. Lin, and M. Hou, "Chromium nitride films on stainless steel as bipolar plate for proton exchange membrane fuel cell," Journal of Power Sources, vol. 194, no. 2, pp. 976-980, 2009.

[27] K. Feng, Y. Shen, D. Liu, P. K. Chu, and X. Cai, "Ni-Cr Coimplanted 316L stainless steel as bipolar plate in polymer electrolyte membrane fuel cells," International Journal of Hydrogen Energy, vol. 35, no. 2, pp. 690-700, 2010.

[28] H. S. Choi, D. H. Han, W. H. Hong, and J. J. Lee, "(Titanium, chromium) nitride coatings for bipolar plate of polymer electrolyte membrane fuel cell," Journal of Power Sources, vol. 189, no. 2, pp. 966-971, 2009.

[29] C.-Y. Chung, S.-K. Chen, P.-J. Chiu, M.-H. Chang, T.-T. Hung, and T.-H. Ko, "Carbon nanotubular fiber composite for fuel cell bipolar plates," Fuel Cells, vol. 3, p. 14, 2002.

[30] J. Wind, R. Späh, W. Kaiser, and G. Böhm, "Metallic bipolar plates for PEM fuel cells," Journal of Power Sources, vol. 105, no. 2, pp. 256-260, 2002.

[31] S. H. Wang, J. Peng, and W. B. Lui, "Surface modification and development of titanium bipolar plates for PEM fuel cells," Journal of Power Sources, vol. 160, no. 1, pp. 485-489, 2006.

[32] W. Yoon, X. Huang, P. Fazzino, K. L. Reifsnider, and M. A. Akkaoui, "Evaluation of coated metallic bipolar plates for polymer electrolyte membrane fuel cells," Journal of Power Sources, vol. 179, no. 1, pp. 265-273, 2008.

[33] M. Evesque, M. Keddam, and H. Takenouti, "The formation of self-assembling membrane of hexadecane-thiol on silver to prevent the tarnishing," Electrochimica Acta, vol. 49, no. 17-18, pp. 2937-2943, 2004. 

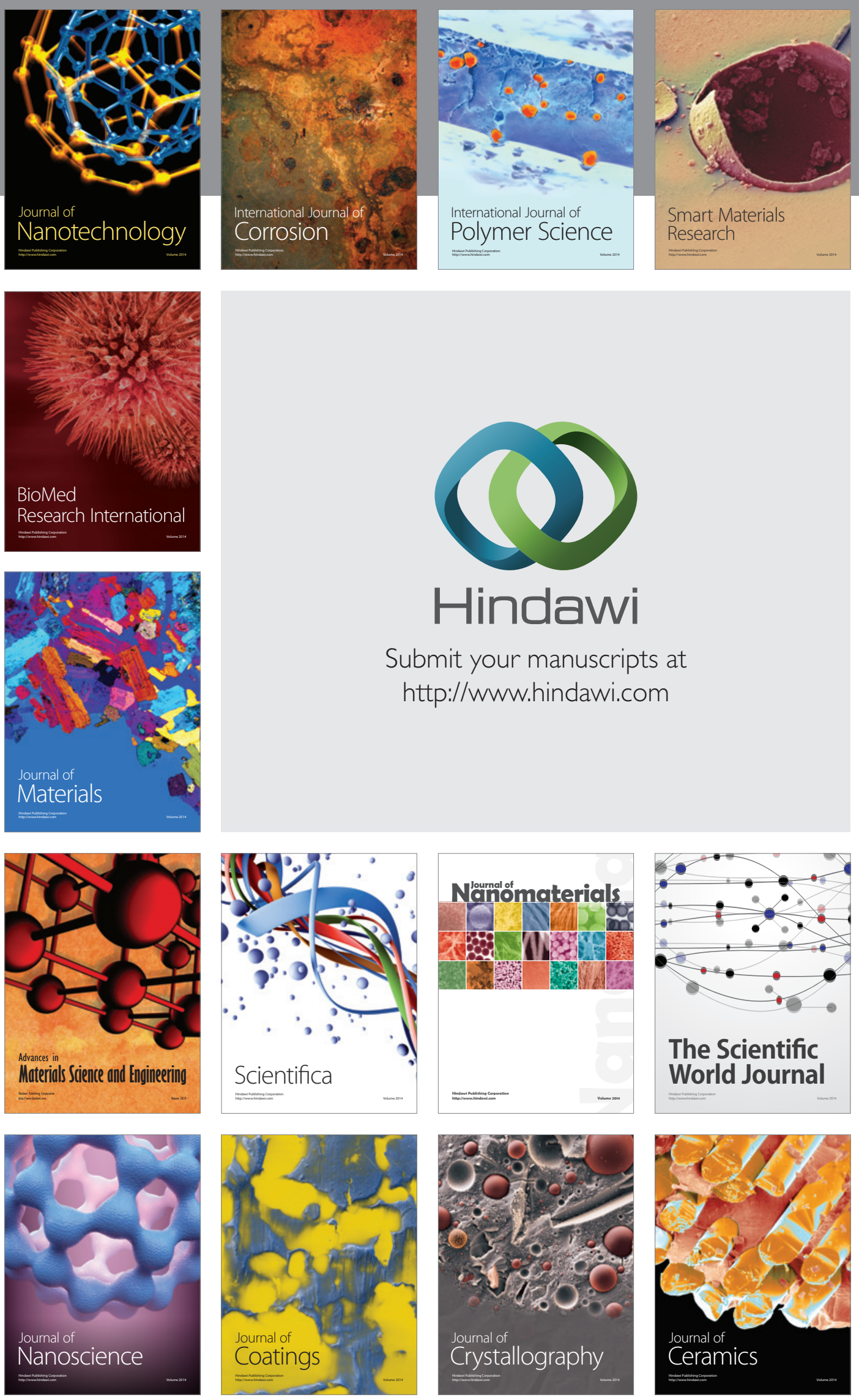

The Scientific World Journal

Submit your manuscripts at

http://www.hindawi.com

\section{World Journal}

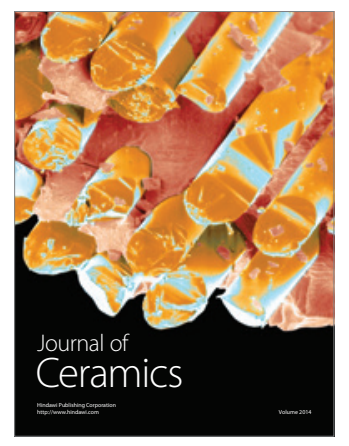

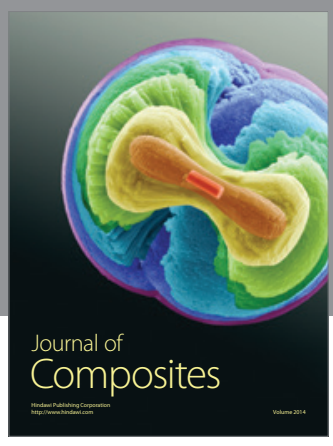
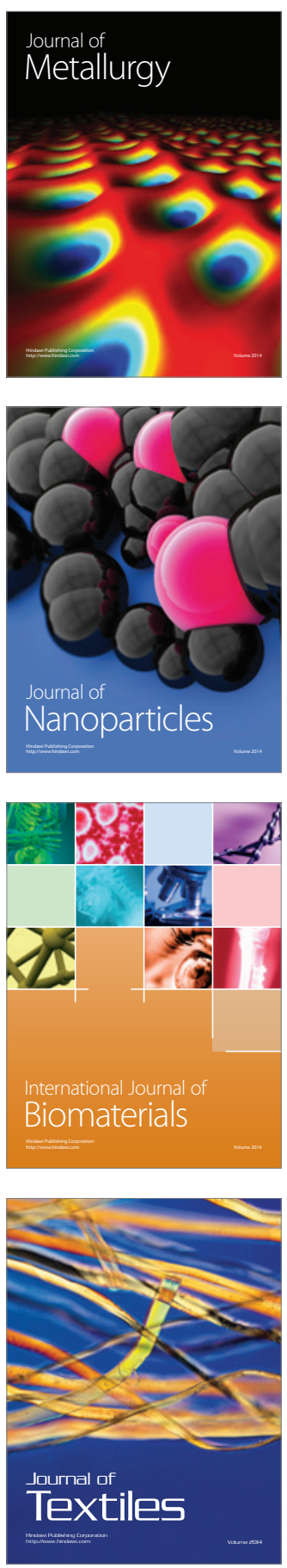